\title{
A modular environmental and economic assessment applied to the production of Hermetia illucens larvae as a protein source for food and feed
}

\author{
Raphaela Spykman $^{1}$ - Sayed Mahdi Hossaini ${ }^{1}$ · Daniela A. Peguero ${ }^{2}$ - Ashley Green ${ }^{2,3}$ - Volker Heinz ${ }^{1}$. \\ Sergiy Smetana ${ }^{1}$ (1)
}

Received: 5 July 2021 / Accepted: 29 September 2021 / Published online: 9 October 2021

(c) The Author(s) 2021

\begin{abstract}
Purpose The inclusion of insect protein into the food system has been proposed as a promising solution to ensure future food security and mitigate negative environmental impacts related to food production. However, the market volume for edible insects in Europe is still small; consequently, producers need a decision-support system to ensure the sustainable upscaling of the sector. The study analyzed environmental and economic impacts of insect production to identify the most eco-efficient production scenarios.

Methods A novel modular eco-efficiency assessment approach was developed to analyze the production of dried Hermetia illucens larvae. An exemplary, industrial-scale insect production system was disaggregated into a total of 29 module variants that can be combined into 4608 distinct production scenarios, which are characterized by different feeds, energy efficiencies, and processing technologies. Environmental life cycle and cost assessments were carried out for each module variant, and eco-efficiency assessment was used to jointly assess these two sustainability dimensions. Additionally, the influence of the insect feed on the production system performance and impact was investigated by employing feed-specific scaling factors. These were used to aggregate module results into production scenario results.

Results and discussion The most eco-efficient production scenarios include energy-efficient rearing facilities that rely on blanching and microwave drying for processing. The insect feed is the largest contributor to the environmental impacts and costs, but from an eco-efficiency standpoint, the choice of feed might not be crucial. Waste-type feeds (e.g., manure, fruit, and vegetable waste) have low environmental impacts and costs, but the production scenarios based on these feeds are less efficient. The low impacts of the feed are offset by higher impacts during the rearing and processing stages. Conversely, scenarios based on higher quality feeds (e.g., by-products like wheat middlings or distiller's grains) require less resources, but the initial feed impacts and costs are higher. Moreover, of the feed types studied, only highly processed ones, such as compound chicken feed, should be avoided for insect rearing.

Conclusions The developed modular assessment approach is efficient in assessing multiple potential insect production scenarios. It can be adapted to incorporate additional variations of the production system via additional modules. Limitations include the potential for redundant module combinations and the up-front time investment needed. Finally, the results are sensitive to methodological choices: thus, these should be carefully considered and communicated during the design of the modular assessment system.
\end{abstract}

Keywords Black soldier fly · Life cycle assessment · Cost assessment · Eco-efficiency · Insects for food and feed · Modular assessment $\cdot$ Scaling factors

\section{Introduction}

Communicated by Arnaud Hélias

Sergiy Smetana

s.smetana@dil-ev.de

Extended author information available on the last page of the article

\subsection{Edible insects}

To ensure future food security, the global food production needs to be scaled up and intensified. But resources like 
water and arable land are limited, and agriculture, especially livestock production, already exerts substantial pressures on the environment. The inclusion of edible insects into the food system, for direct consumption or as livestock feed, has been proposed as a promising solution. The proteinrich insect biomass can, for example, be used to (partially) replace other protein sources like fishmeal or soymeal in aquaculture or poultry feed (Sánchez-Muros et al. 2014; Henry et al. 2015; De Marco et al. 2015). Edible insects offer several advantages over traditional livestock: a higher feed conversion efficiency, lower land use and greenhouse gas emissions, and the ability to valorize waste and side streams to name a few (van Huis 2013). For example, replacing 50\% of animal products with mealworm larvae could lead to a $37 \%$ reduction of agricultural land use for food, assuming that insects would be fed with the same diet as traditional livestock (Alexander et al. 2017).

Industrial production of edible insects can generally be separated into four main activities: the preparation of the feeding substrate, the rearing and harvesting of the insects, the processing of the insects, and breeding of new insects (Kok 2021). The production system can be based on a continuous or a batch process and can vary considerably in duration and design, depending on the type of insect that is farmed. Insect feed and operating conditions (such as temperature, ventilation, lighting, and population density) need to be adjusted to the insect species' needs (Cortes Ortiz et al. 2016). Some typical rearing durations, depending on feed and other conditions, are 12-34 weeks for yellow mealworms (Tenebrio molitor), 7-24 weeks for house crickets (Acheta domesticus), and 3-5 weeks for Black soldier fly (BSF, Hermetia illucens) (Oonincx et al. 2015).

Once the insects reach the desired size, they are separated (or harvested) from the remaining feeding substrate and frass, washed, and then killed, commonly by blanching or freezing (Dossey et al. 2016). Further processing steps can include drying, grinding, and extraction of proteins or lipids, depending on the desired final output (for example, dried whole insects, protein meal, or insect fat) (Melgar-Lalanne et al. 2019). Additionally, emerging processing technologies (pulsed electric fields, microwave drying, high-pressure processing, etc.) are also garnering the interest of insect producers (Shorstkii et al. 2020; Smetana et al. 2020; Alles et al. 2020). The rearing residues can be used as a fertilizer or soil enhancer with similar properties as compost (Kawasaki et al. 2020).

Considering recent improvements in clarification of legislative barriers (EFSA Panel on Nutrition et al. 2021), it is envisioned that by 2023, the amount of protein sourced from insects in Europe could double (Guiné et al. 2021). As the insect industry continues to grow rapidly, a decision support system is needed to sustainably upscale insect production in Europe.

\subsection{Assessment methods}

Life cycle assessment ( $L C A)$, an internationally standardized framework, is a comprehensive method for quantifying environmental impacts across the life cycle of products, processes, and more complex systems (Hellweg and Milà i Canals 2014). It is an iterative approach that consists of the phase's goal and scope definition, inventory analysis, impact assessment, and interpretation. In a conventional LCA, a product's life cycle is modeled through material flow models from "cradle-to-grave" or other system boundaries, depending on the goal and scope of the assessment. Based on this life cycle inventory, the environmental impacts are assessed and related to the functional unit of the studied system. LCA can be a timeand data-intensive task, especially when many alternative value chains or life cycles are to be analyzed in a comparative assessment. A modular LCA approach has been developed to streamline such comparative assessments (Jungbluth et al. 2000; Rebitzer 2005; Buxmann et al. 2009; Steubing et al. 2016). In modular LCA, a production system is broken down into independent modules which can be recombined to represent different value chains or production scenarios. Then each module is modeled and assessed separately, and the module results are aggregated to value chain results using scaling factors. This can save time compared to conventional LCA, where each alternative value chain is generally modeled individually throughout the life cycle. However, an up-front time investment is needed in modular LCA for definition of modules and scaling factors. A detailed description of the method can be found in the literature (Rebitzer 2005).

Life cycle costing (LCC) is a technique to assess the costs of a product or a system across its life cycle. In its conventional form, it is a purely economic assessment, similar to the total cost of ownership approach. Environmental LCC was developed as an extension of this to align with LCA. In addition to the direct internal monetary costs, it seeks to also incorporate certain external costs caused by environmental impacts. The environmental impacts of a system need to be identified before their externalities can be considered in an environmental LCC. Consequently, an LCA must be carried out alongside or prior to an environmental LCC. Both assessments must be based on the same product system, defined by equivalent goal and scope statements (Hunkeler et al. 2008).

Eco-efficiency assessment (EEA) considers the environmental and value (economic) aspects of a production system in parallel. The system's environmental impact (assessed through LCA) is set in relation to a value indicator (e.g., monetary costs assessed through LCC) as described by the international standard (ISO 14045 2012). 
EEA is a relative assessment method which allows for comparative assertions between several alternative products or scenarios but not for absolute result conclusions (Saling 2016).

\subsection{Literature review}

Previous sustainability assessment studies of insect production for food and feed, published in the last decade, concentrated on the black soldier fly (BSF), Hermetia illucens (Table 1) (Smetana et al. 2021). Most studies assessed environmental aspects but only a few also considered economic aspects of insect cultivation (Roffeis et al. 2018; Pleissner and Smetana 2020; Ites et al. 2020). Publications on the eco-efficiency of insect production could not be identified.

Most LCAs performed for cradle-to-gate boundaries indicate that the production of the feeding substrate is the main contributor to the global warming potential of insect production (Oonincx and de Boer 2012; Smetana et al. 2016, 2019; Bosch et al. 2019; Ites et al. 2020). Land use, eutrophication, and acidification are also predominantly attributable to the feed (van Zanten et al. 2015; Salomone et al. 2017; Smetana et al. 2019; Bava et al. 2019; Ites et al. 2020). The system boundaries of the studies range from "cradle to farm gate," which includes the stage production of feeding substrate and insect farming, to "cradle to processing gate," which also includes processing steps like drying or grinding. Only one study also included the use phase in the assessment ("cradle to plate") (Smetana et al. 2015). Half the studies included impacts from infrastructure (i.e., buildings and equipment). The sole LCC study of insect production (Roffeis et al. 2018) found that labor accounted for the largest share of the system's costs $(67 \%)$, followed by the feed $(15 \%)$.

The available studies in the literature rely on several different impact assessment methods and midpoint and endpoint

Table 1 Impacts of $H$. illucens production indicated in published studies (impacts on climate, land use, and water use are included)

\begin{tabular}{|c|c|c|c|c|c|}
\hline Studies & Reference unit & System boundaries & Diet for insects & Method & Impacts \\
\hline \multirow[t]{2}{*}{ Bava et al. (2019) } & \multirow[t]{2}{*}{$1 \mathrm{~kg}$ DM whole larvae } & \multirow[t]{2}{*}{$\begin{array}{l}\text { Cradle to processing } \\
\text { gate }\end{array}$} & Control hen diet & \multirow[t]{2}{*}{$\begin{array}{l}\text { ILCD } 2011 \text { Midpoint } \\
\text { V1.03 }\end{array}$} & $\begin{array}{l}\text { CC: } 5.76 \\
\text { LU1: } 94.7 \\
\text { WD: } 1.26\end{array}$ \\
\hline & & & $\begin{array}{l}\text { Food processing } \\
\text { by-products (okara, } \\
\text { maize distiller's } \\
\text { grains, wet brewer's } \\
\text { spent grains) }\end{array}$ & & $\begin{array}{l}\text { CC: } 0.68-1.95 \\
\text { LU1: } 1.25-4.92 \\
\text { WD: } 0.75-1.16\end{array}$ \\
\hline Bosch et al. (2019) & $1 \mathrm{~kg}$ of protein & Cradle to farm gate & $\begin{array}{l}27 \text { different feeding } \\
\text { substrates (using } \\
\text { data from several } H \text {. } \\
\text { illucens studies) }\end{array}$ & Separate indicators & $\begin{array}{l}\text { CC: } 3-19 \\
\text { LU: } 0-67\end{array}$ \\
\hline Ites et al. (2020) & $\begin{array}{l}1 \mathrm{~kg} \mathrm{DM} \text { whole } \\
\text { larvae* }\end{array}$ & $\begin{array}{l}\text { Cradle to processing } \\
\text { gate }\end{array}$ & $\begin{array}{l}\text { Expired food products, } \\
\text { potato peels, } \\
\text { brewery grains }\end{array}$ & $\begin{array}{l}\text { IMPACT } 2002+ \\
\text { Version } 2.21\end{array}$ & $\begin{array}{l}\text { CC: }-6.42 \text { to } 2.0 \\
\text { LU: }-16.8 \text { to }-0.006\end{array}$ \\
\hline Maiolo et al. (2020) & $\begin{array}{l}1 \mathrm{~kg} \text { DM defatted } \\
\text { meal }\end{array}$ & $\begin{array}{l}\text { Cradle to processing } \\
\text { gate }\end{array}$ & $\begin{array}{l}\text { Cereal by-products/ } \\
\text { grains }\end{array}$ & $\begin{array}{l}\text { CML-IA baseline } \\
\text { V3.05; AWARE }\end{array}$ & $\begin{array}{l}\text { CC: } 2.0-4.9 \\
\text { AWARE: } 2.6-7.2\end{array}$ \\
\hline Roffeis et al. (2015) & $\begin{array}{l}1 \mathrm{~kg} \mathrm{DM} \text { whole } \\
\text { larvae* }\end{array}$ & $\begin{array}{l}\text { Cradle to processing } \\
\text { gate }\end{array}$ & Manure diet & ReCiPe 2008 & $\begin{array}{l}\text { LU: } 4.4-7.7 \\
\text { WD: } 113.9-187.6\end{array}$ \\
\hline $\begin{array}{l}\text { Roffeis et al. (2017, } \\
\text { (2020) }\end{array}$ & $1 \mathrm{~kg}$ DM whole larvae & $\begin{array}{l}\text { Cradle to processing } \\
\text { gate }\end{array}$ & $\begin{array}{l}\text { Manures and organic } \\
\text { wastes }\end{array}$ & $\begin{array}{l}\text { ReCiPe method (V } \\
\text { 1.11) }\end{array}$ & $\begin{array}{l}\text { CC: } 4.5-12 \\
\text { ALO: } 5.5-61 \\
\text { WD: } 8.5-11\end{array}$ \\
\hline Salomone et al. (2017) & $\begin{array}{l}1 \mathrm{~kg} \mathrm{DM} \text { whole } \\
\text { larvae* }\end{array}$ & $\begin{array}{l}\text { Cradle to processing } \\
\text { gate }\end{array}$ & Mixed food waste & $\begin{array}{l}\text { CML } 2 \text { baseline } 2000 \\
\text { method and GWP } \\
100 \mathrm{a} \text { v. } 1.02 \text { method }\end{array}$ & $\begin{array}{l}\text { CC: } 1.0 \\
\text { LU: } 0.022\end{array}$ \\
\hline Smetana et al. (2016) & $\begin{array}{l}1 \mathrm{~kg} \text { DM defatted } \\
\text { meal }\end{array}$ & $\begin{array}{l}\text { Cradle to processing } \\
\text { gate }\end{array}$ & $\begin{array}{l}\text { Various standard } \\
\text { feeds, manures, } \\
\text { wastes }\end{array}$ & $\begin{array}{l}\text { ReCiPe V1.08 and } \\
\text { IMPACT } 2002+\end{array}$ & $\begin{array}{l}\text { CC: } 1.36-15.1 \\
\text { LU: } 0.0032-7.03\end{array}$ \\
\hline Smetana et al. (2019) & $1 \mathrm{~kg}$ DM dried meal & $\begin{array}{l}\text { Cradle to processing } \\
\text { gate }\end{array}$ & $\begin{array}{l}\text { Side streams from } \\
\text { milling, alcohol } \\
\text { production, } \\
\text { breweries }\end{array}$ & $\begin{array}{l}\text { IMPACT } 2002+\text { and } \\
\text { IMPACT World for } \\
\text { WF }\end{array}$ & $\begin{array}{l}\text { CC: } 5.3 \\
\text { LU: } 1.9 \\
\text { WU: } 2.8\end{array}$ \\
\hline
\end{tabular}

AWARE water use in $\mathrm{m}^{3}$ (Boulay et al. 2018), $A L O$ agricultural land occupation, $C C$ climate change or global warming potential in kg $\mathrm{CO}_{2}$-eq, $L U$ land use or land occupation in $\mathrm{m}^{2}$ (arable), $L U 1$ land use in $\mathrm{kg} \mathrm{C}$ deficit, $W D$ water depletion or water resource depletion in $\mathrm{m}^{3}$ or $\mathrm{m}^{3}$ eq., $W U$ water use in $\mathrm{L}$ deprived. *Recalculated for $1 \mathrm{~kg} \mathrm{DM}$ of whole larvae 
indicators to report their results. The three most common impact categories include climate change, energy use, and land use; and these are the categories for which insect production has relevant impacts. The choice of allocation method also varies across studies. Some studies assign the total system impact to the insect output (Salomone et al. 2017; Maiolo et al. 2020), while others rely on economic allocation and thereby also assign some impact to the by-product (Smetana et al. 2016; Salomone et al. 2017; Roffeis et al. 2017, 2020; Ites et al. 2020). Yet other studies employ system expansion and consider the avoided production of compost, fertilizers, fishmeal, or even food products (Salomone et al. 2017; Mertenat et al. 2019; Smetana et al. 2019; Bava et al. 2019).

Table 1 lists select methodological aspects and results of LCA studies of the production of H. illucens larvae for food and feed. Elements of the studied systems, such as the reference unit, the system boundaries, and insect diet, differed greatly, as do the applied impact assessment methods and LCA results. While the existing scientific assessments provide useful insights into the environmental performance of insects as food and feed, the research design varies widely between studies and does not allow for a direct benchmarking of production systems (Smetana et al. 2021). A comprehensive assessment tool for the systematic comparison of different production systems is needed to aid decisionmakers in sustainably upscaling edible insect production.

\subsection{Objective}

The motivation of this study is to better understand the environmental impacts and costs associated with the production of insects and use these insights to provide decision support to stakeholders in the edible insect sector. The goal is to identify the most eco-efficient way of producing insects as a protein source for food and feed. To that end, a modular approach was developed to systematically model and assess different industrial-scale production scenarios and analyze trade-offs between choices along the value chain, with a specific focus on how insect feed influences total system performance and resulting environmental and economic impacts and final eco-efficiency.

\section{Methods}

\subsection{Overview of the applied modular assessment method}

This study employs a modular eco-efficiency approach, which was developed as a combination of the modular LCA approach and the standardized EEA method. It comprises three stages: the modularization of the production system, the assessment of the defined modules, and the assessment of production scenarios (Fig. 1). Like LCA and EEA, this approach is iterative: the stages build on one another but changes in one stage generally require adjustments in the others.

The goal of the first phase, modularization, is to define a production system to be studied and break it down into independent modules, which can be recombined to represent different production scenarios. Modules can exist in one or more variants, which represent alternatives within production scenarios (e.g., different processing technologies). The production system was disaggregated into ten modules and a total of 29 module variants. To aggregate these modules to scenarios, scaling factors are needed. These determine the amount (or reference flow) of each module that is needed to fulfill the module's function in the production scenario (e.g., how much feed is needed to produce $1 \mathrm{~kg}$ of insect output). Six sets of scaling factors, which depend on the main determinant of system performance, the feed, were calculated (see Sect. 2.2).

The second phase, assessment of modules, consists of a life cycle inventory analysis of each module variant (quantification of inputs and outputs) followed by an environmental assessment (LCA) and cost assessment (LCC). This yields a set of results for each module variant which can be aggregated to represent results on a production scenario level (see Sect. 2.3).

In phase three, the production scenarios to be assessed are determined, and the production scenario results are calculated. At this stage, the module results can be used for multiple purposes. Specific production scenarios can be analyzed by combining the module variants that best represent it. Alternatively, the variant results can be used to determine a best-case or worst-case scenario out of all possible module variant combinations (e.g., which scenario has the highest climate change impact or lowest cost). In this study, the goal is to determine the most eco-efficient production scenario. Six scenarios were selected, we then calculated the scenario results and carried out an eco-efficiency assessment of these results (see Sect. 2.4).

\subsection{Phase 1-Modularization}

\subsubsection{Description of studied system}

The function of the studied system is the production of protein for food and feed from dried BSF larvae, represented by the functional unit $1 \mathrm{~kg}$ crude protein. The cradle-togate system boundaries include the production of the feeding substrate, the production of seed larvae, and the rearing, harvesting, and processing of the larvae (Fig. 2). The studied system has two outputs: the main product, dried larvae, and the by-product residual biomass (consisting of leftover feeding substrate, insect droppings, and other organic wastes). 
Fig. 1 Applied method for a modular eco-efficiency assessment of different edible insect production scenarios

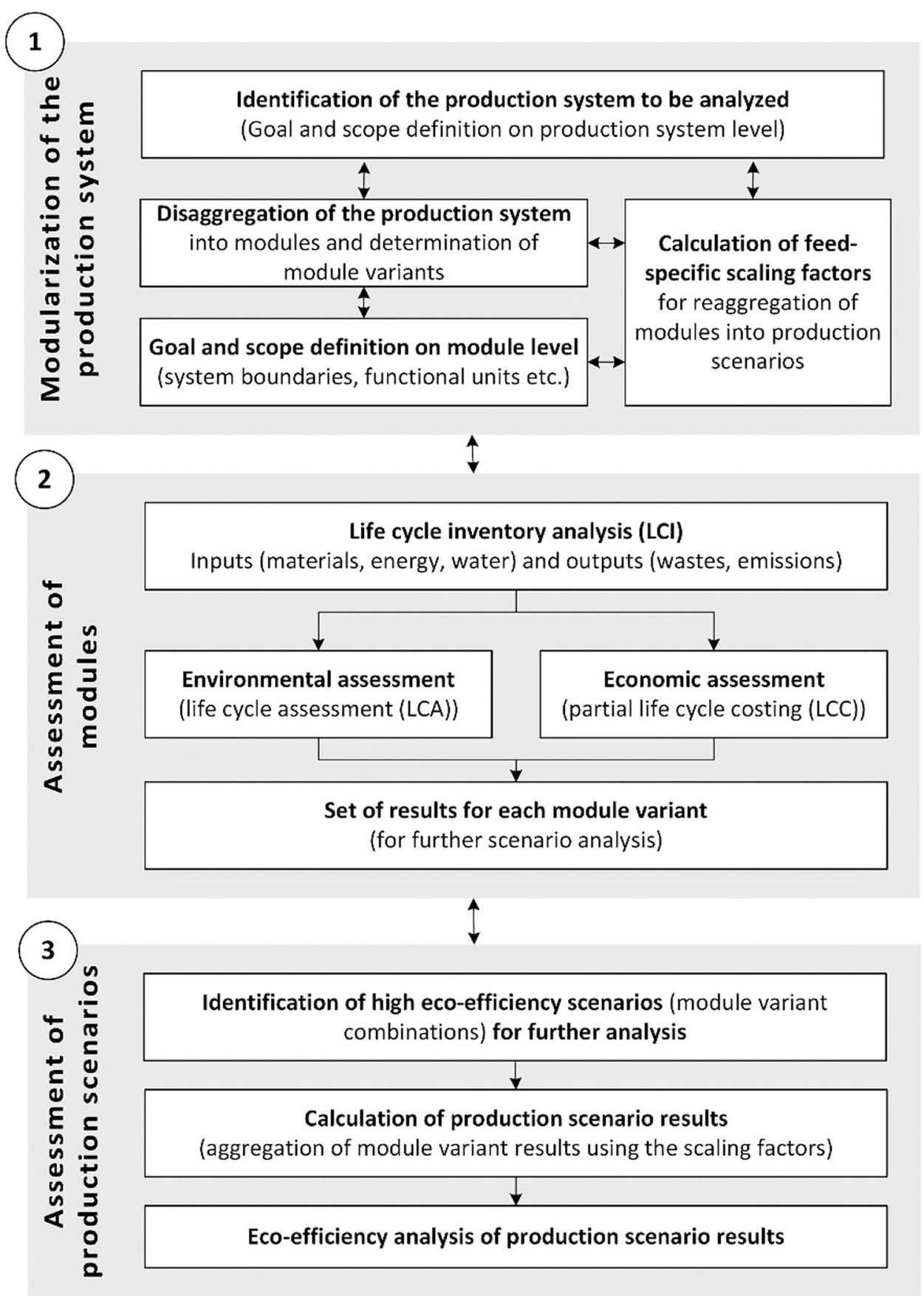

This multifunctionality is handled via system expansion: the residual biomass output is handled as avoided compost production, because it is assumed to have similar properties. Multifunctionality in the background system (specifically the production of the feed ingredients) is handled via economic allocation.

\subsubsection{Modularization-preliminary considerations}

The modularization of the studied production system was carried out according to the following preliminary considerations. The production system has a function, in this case the production of protein in the form of dried BSF larvae. A module fulfills a subfunction of the production system and has defined module boundaries. Modules should encompass activities that are easily separable from upstream, downstream, and, if applicable, parallel activities. Activities that are expected to contribute a significant share to the environmental or economic impact of the system should be assigned to a separate module to facilitate contribution analysis. Modules should be defined at positions in the production chain where alternatives arise. This way the 


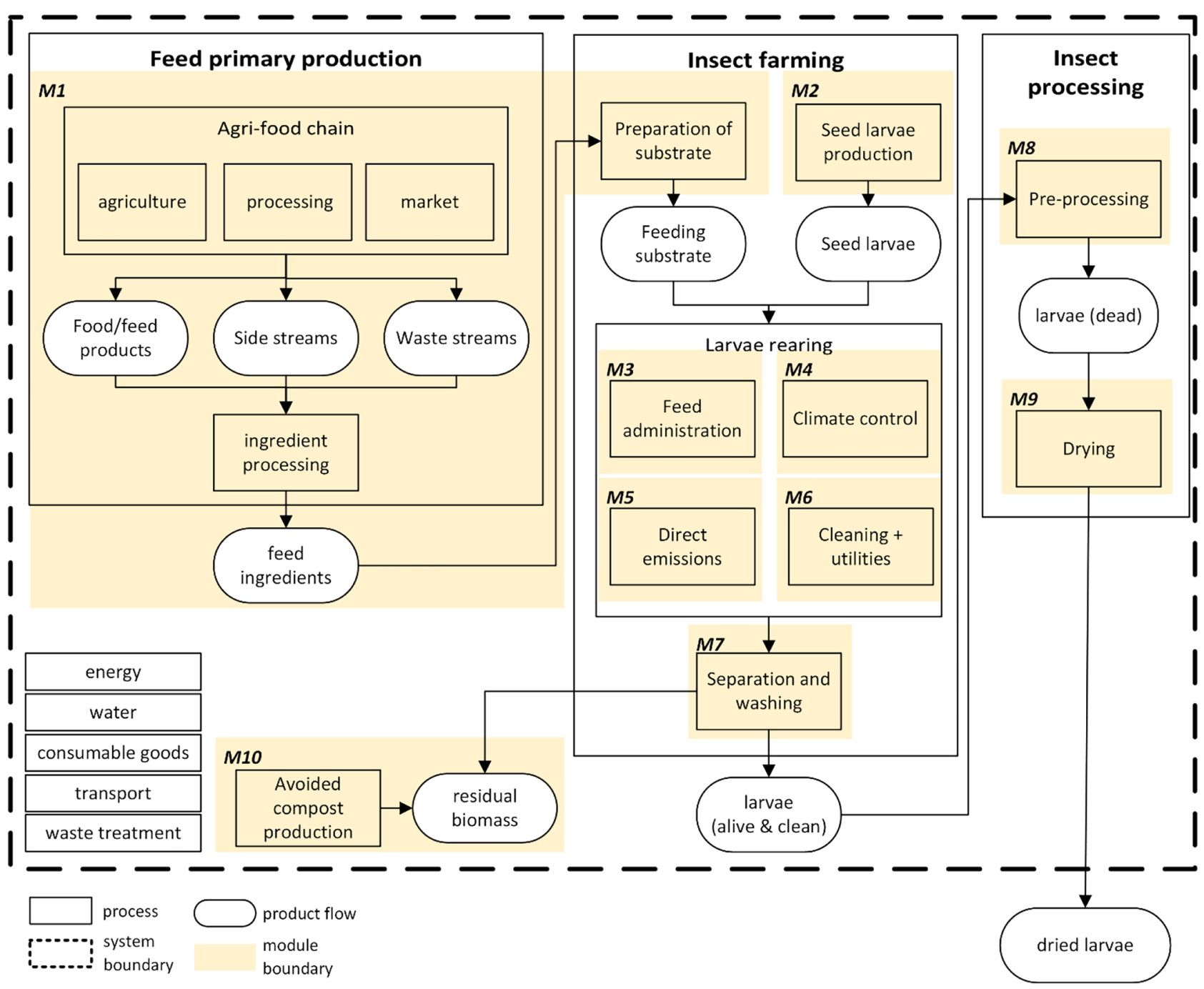

Fig. 2 Scheme of insect production system modularized for further analysis

alternatives can be represented by different module variants. Furthermore, modules may need to be defined out of methodological necessity (e.g., to handle multifunctionality of the system). And lastly, data availability plays a significant role because a production process can only be disaggregated into modules when there is sufficient data for modeling.

\subsubsection{Modularized production system}

The previously defined hypothetical production system was disaggregated into ten modules according to the above considerations (Fig. 2). Module M1 encompasses the production of the feeding substrate, including the primary production of the feed ingredients, their transport to the insect rearing facility, and the preparation of the feeding substrate prior to feeding. The production of seed larvae (5-day-old larvae) takes place in the breeding and nursery unit which is contained in module M2. The feeding substrate from M1 and the seed larvae from $\mathrm{M} 2$ are inputs into the insect rearing unit, which is divided into modules M3-M7. M3 entails the internal transport and distribution of feed. The climate control system of the unit is represented in M4. Utilities, cleaning, and internal transport within the unit are consolidated in M6, management of the rearing unit. Lastly, the insects' metabolic emissions during the rearing phase are covered in M5. At the end of the rearing phase, the insects are separated from the residual biomass and washed, described by module M7. The processing stage comprised two modules: M8 encompasses the killing (pre-processing) of the larvae, and M9 entails the drying step, yielding the final dried larvae product output. To account for the co-product residual biomass via system expansion, the avoided compost production (M10) was included as a system credit.

Subsequently, a total of 29 module variants was defined for the ten modules. For module M1, these are based on different feed ingredients. Modules M2, M4, and M6 have 
Table 2 Overview of module functions and module variants

\begin{tabular}{|c|c|c|c|c|}
\hline \multicolumn{2}{|c|}{ Module } & \multirow{2}{*}{$\begin{array}{l}\text { Function } \\
\text { Production and transport of feed } \\
\text { ingredients, preparation of substrate }\end{array}$} & \multicolumn{2}{|l|}{ Variants } \\
\hline M1 & Feed production & & $\begin{array}{l}6 \text { variants based on different } \\
\text { substrate ingredients (traditional } \\
\text { feed ingredients; agri-food by- } \\
\text { products; waste streams) }\end{array}$ & $\begin{array}{l}\text { M1.1 Gainesville fly diet } \\
\text { M1.2 Compound chicken feed } \\
\text { M1.3 Distiller's grains } \\
\text { M1.4 Wheat middlings } \\
\text { M1.5 Fruit and vegetable waste } \\
\text { M1.6 Poultry manure }\end{array}$ \\
\hline M2 & Breeding and nursery unit & $\begin{array}{l}\text { Production of seed larvae for } \\
\text { rearing unit, including } \\
\text { maintenance of adult colony and } \\
\text { initial rearing of freshly hatched } \\
\text { larvae }\end{array}$ & $\begin{array}{l}4 \text { variants based on energy and } \\
\text { water consumption scenarios }\end{array}$ & $\begin{array}{l}\text { M2.1 Baseline } \\
\text { M2.2 -10\% energy and water } \\
\text { M2.3 -25\% energy and water } \\
\text { M2.4 -50\% energy and water }\end{array}$ \\
\hline M3 & Feeding & $\begin{array}{l}\text { Internal transport and distribution } \\
\text { of feeding substrate to larvae }\end{array}$ & 1 variant & M3 \\
\hline M4 & Climate system & $\begin{array}{l}\text { Provision of adequate climatic } \\
\text { conditions in the rearing unit } \\
\text { (temperature, humidity, and } \\
\text { ventilation) }\end{array}$ & $\begin{array}{l}4 \text { variants based on energy and } \\
\text { water consumption scenarios }\end{array}$ & $\begin{array}{l}\text { M4.1 Baseline } \\
\text { M4.2 -10\% energy } \\
\text { M4.3 -25\% energy } \\
\text { M4.4 -50\% energy }\end{array}$ \\
\hline M5 & Direct emissions & $\begin{array}{l}\text { Accounting of metabolic emissions } \\
\text { of the larvae rearing }\end{array}$ & 1 variant & M5 \\
\hline M6 & Management of rearing unit & $\begin{array}{l}\text { Cleaning activities, utility } \\
\text { consumption, and internal } \\
\text { transport within the rearing unit }\end{array}$ & $\begin{array}{l}4 \text { variants based on energy and } \\
\text { water consumption scenarios }\end{array}$ & $\begin{array}{l}\text { M6.1 Baseline } \\
\text { M6.2 -10\% energy and water } \\
\text { M6.3 -25\% energy and water } \\
\text { M6.4 -50\% energy and water }\end{array}$ \\
\hline M7 & Harvest & $\begin{array}{l}\text { Separation of larvae from residual } \\
\text { biomass and washing of larvae }\end{array}$ & 1 variant & M7 \\
\hline M8 & Pre-processing & Killing of insect larvae & $\begin{array}{l}4 \text { variants based on different } \\
\text { technologies }\end{array}$ & $\begin{array}{l}\text { M8.1 Blanching } \\
\text { M8.2 Freezing } \\
\text { M8.3 High pressure processing } \\
\text { M8.4 Microwave sterilization }\end{array}$ \\
\hline M9 & Drying & $\begin{array}{l}\text { Drying of insect larvae to residual } \\
\text { moisture content of } 5 \%\end{array}$ & $\begin{array}{l}3 \text { variants based on different } \\
\text { technologies }\end{array}$ & $\begin{array}{l}\text { M9.1 Convection drying } \\
\text { M9.2 Freeze-drying } \\
\text { M9.3 Microwave drying }\end{array}$ \\
\hline M10 & Avoided compost production & $\begin{array}{l}\text { Handling of the co-product residual } \\
\text { biomass via system expansion as } \\
\text { avoided compost production }\end{array}$ & 1 variant & M10 \\
\hline
\end{tabular}

variants based on reductions of the specific energy and water consumption. Modules M8 and M9 have variants based on alternative processing technologies. The remaining modules only have one variant each. An overview of all modules and variants is provided in Table 2.

\subsubsection{Scaling factors}

In order to aggregate module results to production scenario results, scaling factors are needed. These scaling factors determine the reference flow of each module that is required to fulfill the system function, for example, how much feeding substrate (M1) and seed larvae (M2) are needed to yield $1 \mathrm{~kg}$ crude protein from dried larvae (functional unit of the system). As previously remarked, the performance of insect rearing systems is dependent on the type of feeding substrate used because it influences aspects like the conversion efficiency, the survival rate and development time of the larvae, and the composition of the final insect output (e.g., protein, lipid, and water content). Therefore, substrate-specific scaling factors were conceived to incorporate the influence of the feed into the assessment of different production chains. As there are six feeding substrates in the system (M1 variants), six sets of scaling factors (SF) were developed (Table 3) for module reference flows related to the production of crude protein from dried larvae. The underlying data was sourced from literature on insect rearing trials. A detailed description of the calculation method can be found in Appendix 1.

\subsection{Phase 2-Assessment of modules}

The second phase, assessment of modules, consists of life cycle inventory modeling of each module variant followed 
Table 3 Feed-specific module scaling factors for the production of $1 \mathrm{~kg}$ crude protein from dried larvae

\begin{tabular}{|c|c|c|c|c|c|c|c|}
\hline \multirow[t]{2}{*}{ Module } & \multirow[t]{2}{*}{ Functional unit of module } & \multicolumn{6}{|c|}{ Feed-specific scaling factors } \\
\hline & & SF1 & SF2 & SF3 & SF4 & SF5 & SF6 \\
\hline M1 & Production of $1 \mathrm{~kg} \mathrm{fm}$ feeding substrate & 43 & 39 & 38 & 53 & 90 & 124 \\
\hline M2 & Production of 1 unit of seed larvae (1000 5-DOL) & 47 & 33 & 54 & 48 & 86 & 92 \\
\hline M3 & Feeding of $1 \mathrm{~kg}$ fm substrate to larvae & 43 & 39 & 38 & 53 & 90 & 124 \\
\hline M4 & Running of climate system for 1 day allocatable to $1 \mathrm{~kg} \mathrm{fm}$ insect output $(1 \mathrm{~kg} * \mathrm{~d})$ & 109 & 100 & 92 & 112 & 232 & 149 \\
\hline M5 & Direct emissions allocatable to $1 \mathrm{~kg} \mathrm{dm}$ insect output & 2 & 2 & 2 & 3 & 3 & 3 \\
\hline M6 & Management activities allocatable to $1 \mathrm{~kg} \mathrm{fm}$ insect output & 6 & 6 & 6 & 8 & 10 & 12 \\
\hline M7 & Harvesting activities allocatable to $1 \mathrm{~kg}$ fm insect output & 6 & 6 & 6 & 8 & 10 & 12 \\
\hline M8 & Killing of $1 \mathrm{~kg}$ fm insects & 6 & 6 & 6 & 8 & 10 & 12 \\
\hline M9 & Removal of $1 \mathrm{~kg}$ water from insect larvae & 4 & 4 & 4 & 5 & 7 & 9 \\
\hline M10 & Substitution of $1 \mathrm{~kg} \mathrm{fm}$ compost with $1 \mathrm{~kg}$ fm residual biomass output & 10 & 13 & 11 & 15 & 17 & 38 \\
\hline
\end{tabular}

$f m$ fresh matter basis, 5-DOL 5-day-old larvae, $d m$ dry matter basis, $S F 1$ Gainesville fly diet, $S F 2$ compound chicken feed, $S F 3$ distiller's grains, SF4 wheat middlings, SF5 fruit and vegetable waste, SF6 poultry manure; units are relative coefficients used for the reference flows

by an environmental assessment (LCA) and cost assessment (LCC). Relevant inventory flows for each module variant were determined and quantified based on the module scopes (see Sect. 2.1) and various literature sources (see Supplementary materials Appendices 1-7). The inventories serve as input data for the subsequent LCA and LCC of each module variant.

The software SimaPro Developer version 8.5.2.0 (PRé Consultants, Netherlands) and the LCI databases Ecoinvent version 3.4 (Wernet et al. 2016) and Agri-footprint version 4.0 (Durlinger et al. 2017) were used for the environmental impact assessment (a complete list of used datasets is provided in Appendix 2). Single score and midpoint indicator results for each module variant were obtained using the impact assessment method ReCiPe 2008 Endpoint and Midpoint, hierarchist $(\mathrm{H})$, version 1.13, with the normalization factors for Europe and the average weighting factors (Europe ReCiPe H/A) (Goedkoop et al. 2009).

LCC analyses were based on prices of variable and capital goods (Appendix 3). Only internal costs were included, taking the perspective of the insect producer. Because the LCC was carried out in parallel to an LCA, environmental externalities were excluded to avoid double counting since the environmental impact is already assessed in the LCA (Rödger et al. 2018). Costs that were assumed to be identical between alternatives (module variants or production scenarios) were excluded because they are inconsequential in a relative assessment. Variable costs were assessed based on the module variant inventories (Appendix 3). Costs of capital goods were partially included where large differences in investment costs of equipment were expected (e.g., different processing technologies in modules M8 and M9). Adjustments for inflation were not included, as reference year was assumed to be the same for all the variants. Furthermore, no discounting was performed as the environmental LCC follows the steady-state model of LCA (Rödger et al. 2018). Revenues (negative costs) of the by-product residual biomass were included in parallel to the system expansion approach in the environmental assessment (M2 and M10). No costs were incurred for module M5 as it consisted only of elementary flows. A full account of module LCI and LCA/ LCC results is in Appendix 4.

\subsection{Phase 3-Assessment of production scenarios}

The following approach was taken to determine the most eco-efficient production scenario out of all possible module variant combination. Note that this approach is the "manual" way of identifying the most eco-efficient option. Module results can also be used as inputs to mathematical optimization models (Steubing et al. 2016).

First, a selection of high eco-efficiency scenarios was made from which the most eco-efficient scenario was to be identified. This was done with the reasoning that a combination of the most eco-efficient module variants leads to the most eco-efficient production scenario. An exception to this is the choice of M1 variant (type of feeding substrate) as this also determines the scaling factor of the scenario and hence influences the final result. Therefore, six scenarios were defined which vary in their M1 variant and respective scaling factors but are identical in their M2-M10 variants. An eco-efficiency assessment was carried out for modules M2-M10 to determine the most eco-efficient variants to be included in the studied scenarios. The LCA results ( $\mathrm{ReC}$ iPe single score) and LCC results of all variants belonging to the same module were normalized by scaling them to their respective average value. For each variant, the normalized cost and the normalized ReCiPe single score were 
Table 4 Main scenario variations considered in the modeling of the study

\begin{tabular}{|c|c|c|c|c|c|c|}
\hline \multirow{4}{*}{$\begin{array}{l}\text { Modules } \\
\text { M1: Production of } \\
\text { feeding substrate }\end{array}$} & \multicolumn{6}{|c|}{ Scenarios and included module variants } \\
\hline & S1 & S2 & S3 & S4 & S5 & S6 \\
\hline & \multicolumn{2}{|c|}{ Conventional feed scenarios } & \multicolumn{2}{|c|}{ By-product scenarios } & \multicolumn{2}{|c|}{ Waste stream scenarios } \\
\hline & $\begin{array}{l}\text { M1.1: Gainesville } \\
\text { fly diet }\end{array}$ & M1.2: chicken feed & $\begin{array}{l}\text { M1.3: distiller's } \\
\text { grains }\end{array}$ & $\begin{array}{l}\text { M1.4: wheat } \\
\text { middlings }\end{array}$ & $\begin{array}{l}\text { M1.5: fruit and } \\
\text { vegetable waste }\end{array}$ & $\begin{array}{l}\text { M1.6: poultry } \\
\text { manure }\end{array}$ \\
\hline $\begin{array}{l}\text { M2: Nursery and } \\
\text { breeding unit }\end{array}$ & \multicolumn{6}{|c|}{ M2.4: $50 \%$ reduction scenario } \\
\hline M3: Feeding & \multicolumn{6}{|l|}{ M3 single variant } \\
\hline M4: Climate system & \multicolumn{6}{|c|}{ M4.4 - 50\% reduction scenario } \\
\hline $\begin{array}{l}\text { M5: Direct emis- } \\
\text { sions }\end{array}$ & \multicolumn{6}{|l|}{ M5 - single variant } \\
\hline $\begin{array}{l}\text { M6: Management } \\
\text { of rearing unit }\end{array}$ & \multicolumn{6}{|c|}{ M4.4-50\% reduction scenario } \\
\hline M7: Harvesting & \multicolumn{6}{|l|}{ M7 - single variant } \\
\hline M8: Pre-processing & \multicolumn{6}{|l|}{ M8.1 - Blanching } \\
\hline M9: Drying & \multicolumn{6}{|c|}{ M9.3 - Microwave drying } \\
\hline $\begin{array}{l}\text { M10: System } \\
\text { expansion }\end{array}$ & \multicolumn{6}{|l|}{ M10 - single variant } \\
\hline
\end{tabular}

then multiplied to yield the eco-efficiency factor. This factor indicates the relative eco-efficiency of the module variants, with the lowest value representing the highest eco-efficiency (Saling et al. 2002). Table 4 shows the six feed-based scenarios (S1-S6) and the module variants of each module that are contained within them.

The second step is to calculate the production scenario results for each of the six production scenarios. This is done by aggregating the module variant results with the respective feed-specific scaling factors (e.g., module variant results of scenario S1 are aggregated using scaling factors SF1). The last step is the eco-efficiency assessment of the production scenario results. This is carried out analogue to the EEA on module level using the aggregated ReCiPe single score and costs results as indicators.

\subsection{Sensitivity analyses}

It is known that the choice of functional unit (Smetana et al. 2016, 2019; Green et al. 2020, 2021) and impact assessment method (Owsianiak et al. 2014) can affect results in LCA studies. The sensitivity of the approach to these methodological choices was tested as follows.

Two alternative functional units, which are commonly used in other LCA studies of insect production, were selected: $1 \mathrm{~kg} \mathrm{dm}$ dried larvae (FU2) and $1 \mathrm{~kg}$ fresh matter ( $\mathrm{fm}$ ) unprocessed larvae (FU3). Additional sets of scaling factors were developed for these functional units to calculate scenario results. This was followed by an eco-efficiency assessment of the scenario results as described above.
Moreover, single score LCA results for each module variant were also calculated with an alternative impact assessment method, IMPACT2002 + . Scenario results were calculated from these alternative results and assessed according to the above method (Appendix 5).

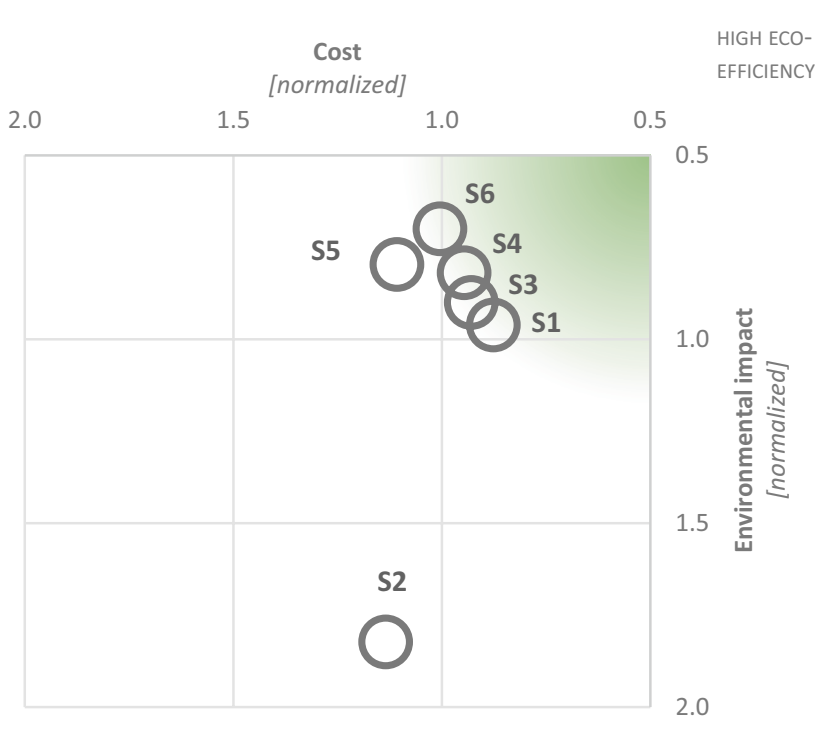

Fig. 3 Eco-efficiency diagram of six feed-based scenarios to produce $1 \mathrm{~kg}$ crude protein from dried H. illucens larvae (ReCiPe method for environmental impact; scenarios: S1, based on Gainesville fly diet; S2, based on compound chicken feed; S3, based on distiller's grains; S4, based on wheat middlings; S5, based on fruit and vegetable waste; S6, based on poultry manure) 
Table 5 Environmental impact, cost, and eco-efficiency results of six feed-based scenarios for the production of $1 \mathrm{~kg}$ crude protein from dried $H$. illucens larvae

\begin{tabular}{llllllll}
\hline \multicolumn{1}{c}{} & Unit & S1 & S2 & S3 & S4 & S5 & S6 \\
\hline $\begin{array}{llllll}\text { Environmental impact assessment } \\
\text { ReCiPe single score }\end{array}$ & $\mathrm{mPt}$ & 1736 & 3291 & 1625 & 1479 & 1439 & 1264 \\
$\begin{array}{l}\text { Climate change } \\
\text { Agricultural land occupation }\end{array}$ & $\mathrm{kg} \mathrm{CO2-eq}$ & 11.89 & 24.19 & 18.00 & 12.18 & 15.09 & 13.97 \\
Water depletion & $\mathrm{m}^{2} \mathrm{a}$ & 9.70 & 17.77 & -0.13 & 9.80 & 0.23 & -1.28 \\
$\begin{array}{l}\text { Economic assessment } \\
\text { Costs }\end{array}$ & $\mathrm{m}^{3}$ & 0.111 & 0.330 & 0.389 & 0.078 & -0.072 & -0.020 \\
Eco-efficiency assessment & $€$ & & & & & & \\
Eco-efficiency factor ReCiPe & & 5.18 & 6.70 & 5.49 & 5.59 & 6.54 & 5.93 \\
\hline
\end{tabular}

Scenarios: S1, based on Gainesville fly diet; S2, based on compound chicken feed; S3, based on distiller's grains; S4, based on wheat middlings; S5, based on fruit and vegetable waste; 6 , based on poultry manure

\section{Results}

The eco-efficiency portfolio of the six studied scenarios identifies S2 (scenario based on chicken feed) as the least eco-efficient option, while the remaining scenarios are clustered at a higher eco-efficiency level (Fig. 3). The calculated eco-efficiency factors (Table 5) indicate that scenario $\mathrm{S} 6$ is the most eco-efficient of the six scenarios, closely followed by S4 (wheat bran), S3 (distiller's grains), and S1 (Gainesville fly diet) and S5, with S2 in last place. The waste stream scenarios S5 (fruit and vegetable waste) and S6 (poultry manure) exhibit a slightly lower environmental impact but slightly higher production costs than the remaining scenarios of the cluster.

Considering the absolute environmental impacts, the waste stream scenarios S5 and S6 have the lowest ReCiPe single score results $(1264-1439 \mathrm{mPt})$, while the climate change impact is lowest for the conventional feed scenario S1 (Gainesville fly diet) and the by-product scenario S4 (wheat middlings) (11.89-12.18 kg CO2eq), which also have the lowest costs $(5.18-5.49 €)$. Scenario S3 (by-product distiller's grains) has one of the lowest land occupation impacts $\left(-0.13 \mathrm{~m}^{2} \mathrm{a}\right)$ along with the waste stream scenarios $\left(-1.28-0.23 \mathrm{~m}^{2} \mathrm{a}\right)$ but the highest water depletion impact $\left(0.389 \mathrm{~m}^{3}\right)$. The chicken feed scenario $\mathrm{S} 2$ has the highest impact across all other impact categories and the highest cost $(6.70 €)$. Overall, there is less variability between the scenarios in the economic assessment than in the environmental assessment.

The production of the feeding substrate (module M1) is the main contributor to the integrated environmental impact (ReCiPe single score) for the conventional feeds and byproduct scenarios (S1-S4; 59-89\%) (Fig. 4). For the waste stream scenarios, the contribution of the modules is distributed more evenly: the rearing and processing stages (M2M9) show a larger absolute and relative contribution here than in the other scenarios. Scenario S6 (poultry manure) has a higher credit (negative impact) from the by-product
Fig. 4 Module contributions to the integrated environmental impact results of six feed-based scenarios for the production of $1 \mathrm{~kg}$ crude protein from dried $H$. illucens larvae (method ReCiPe single score; M1-M10, modules according to Table 2; scenarios: $\mathrm{S} 1$, based on Gainesville fly diet; S2, based on compound chicken feed; S3, based on distiller's grains; S4, based on wheat middlings; S5, based on fruit and vegetable waste; S6, based on poultry manure; total, represents the overall score as a sum pf M1-M10)

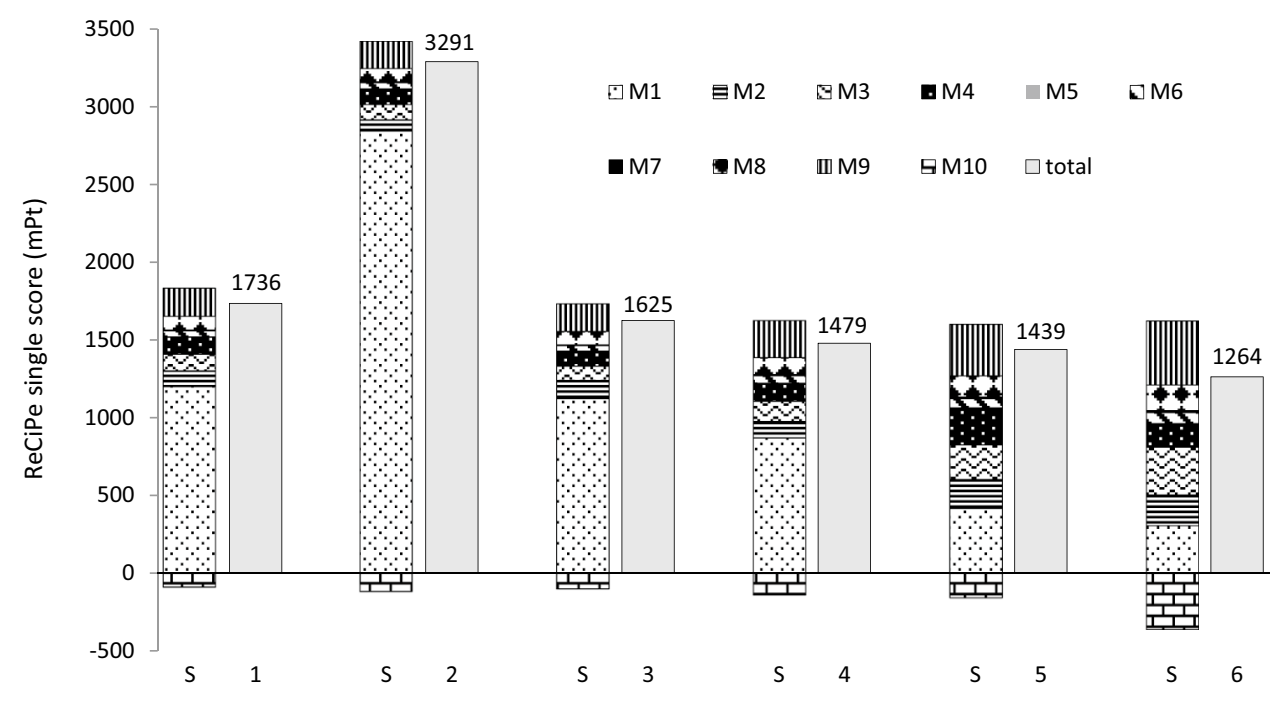


utilization (M10) than the remaining scenarios. Across all scenarios, two modules exhibit only insignificant contributions to the production chain single score: M5 (direct emissions; $\leq 0.2 \%$ ) and $\mathrm{M} 7$ (harvesting; $\leq 1 \%$ ).

The module contribution to the production costs shows a similar pattern with the feeding substrate (M1) as the largest contributor to the overall costs, with a higher share in the traditional feed and by-product scenarios: S1-S4 (55-72\%) than in the waste stream scenarios S5 and S6 (29-38\%) (Fig. 5). The waste stream scenarios on the other hand again show a larger cost contribution from the production of seed larvae (M2), feeding (M3), and drying (M9). Scenario S6 (poultry manure) exhibits a higher revenue from the by-product utilization (M10) than the remaining scenarios.

Figure 6 shows the module contributions for the scenario results of the three midpoint indicators climate change, agricultural land occupation, and water depletion. The module contribution to the climate change impact shows a similar pattern as the contribution to the ReCiPe single score with higher contributions from the feeding substrate in the traditional feeds and by-product scenarios and higher contributions from the rearing and processing stages in the waste stream scenarios (Fig. 6A).

Scenarios S1 (Gainesville fly diet), S2 (chicken feed), and S4 (wheat bran) have a significantly higher agricultural land occupation (ALO) than the remaining scenarios (Fig. 6B), arising almost entirely from the feeding substrate (M1). Scenario S3 (distiller's grains) on the other hand shows a negative ALO result comparable with the waste stream scenarios. But by contrast, the water depletion impact of this scenario is the highest overall) (Fig. 6C).

Scenarios S1-S4 (traditional feeds and by-products) show similar contributions to the water depletion potential from the rearing and processing modules M2-M9 but varying contributions from module M1 (feeding substrate) (Fig. 6C). The main determinant of the water depletion impact in these scenarios is therefore the type of feeding substrate. The waste stream scenarios S4 and S6 have a higher contribution to the water depletion impact from the rearing and processing modules M2-M9. However, since the impact from the feeding substrate for these scenarios was minimal to negative, which, in conjunction with higher credits from M10, led to an overall negative water depletion impact.

\section{Discussion}

\subsection{Main findings}

The findings show the kind of trade-offs present in insect production systems between the upstream impact of the feeding substrate and the impacts occurring during rearing and processing. The production of the feeding substrate is a major contributor to the overall environmental impact (ReCiPe single score) of insect production. But choosing waste-type feed ingredients with no upstream impact does not lead to a significantly lower environmental impact of the final insect output. This is because waste-type feeds generally have a lower nutritional quality leading to a lower conversion efficiency. These effects of the feed on system performance were integrated into the assessment via the feed-specific scaling factors. A lower conversion efficiency influences the environmental impact results negatively in several ways.

To begin with, a lower feed conversion means that more feed is needed to achieve the desired insect output mass. This does not influence the direct impact of the wastetype feed ingredient, as it is considered to enter the system
Fig. 5 Module contributions to the total costs of six feed-based scenarios for the production of $1 \mathrm{~kg}$ crude protein from dried $H$. illucens larvae (scenarios: S1, based on Gainesville fly diet; $\mathrm{S} 2$, based on compound chicken feed; S3, based on distiller's grains; S4, based on wheat middlings; S5, based on fruit and vegetable waste; $\mathrm{S} 6$, based on poultry manure; M1-M10, modules according to Table 2; total, represents the overall score as a sum pf M1-M10)

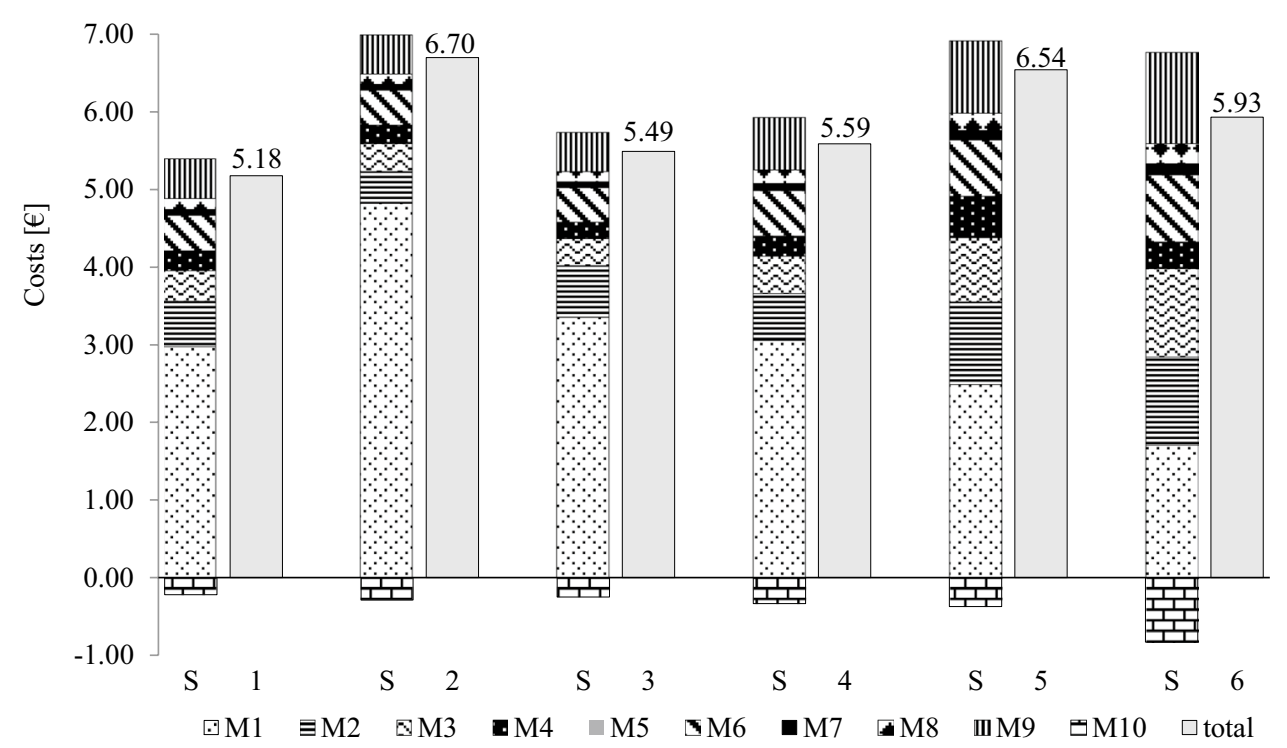


Fig. 6 Module contributions to environmental impacts of six feed-based scenarios to produce edible insects: A climate change impacts, $\mathbf{B}$ agricultural land occupation, $\mathbf{C}$ water depletion impact (functional unit, production of $1 \mathrm{~kg}$ crude protein from dried larvae; method ReCiPe; scenarios: S1, based on Gainesville fly diet; S2, based on compound chicken feed; S3, based on distiller's grains; $\mathrm{S} 4$, based on wheat middlings; S5, based on fruit and vegetable waste; S6, based on poultry manure; M1-M10, modules according to Table 2; total, represents the overall score as a sum pf M1-M10)
(A)

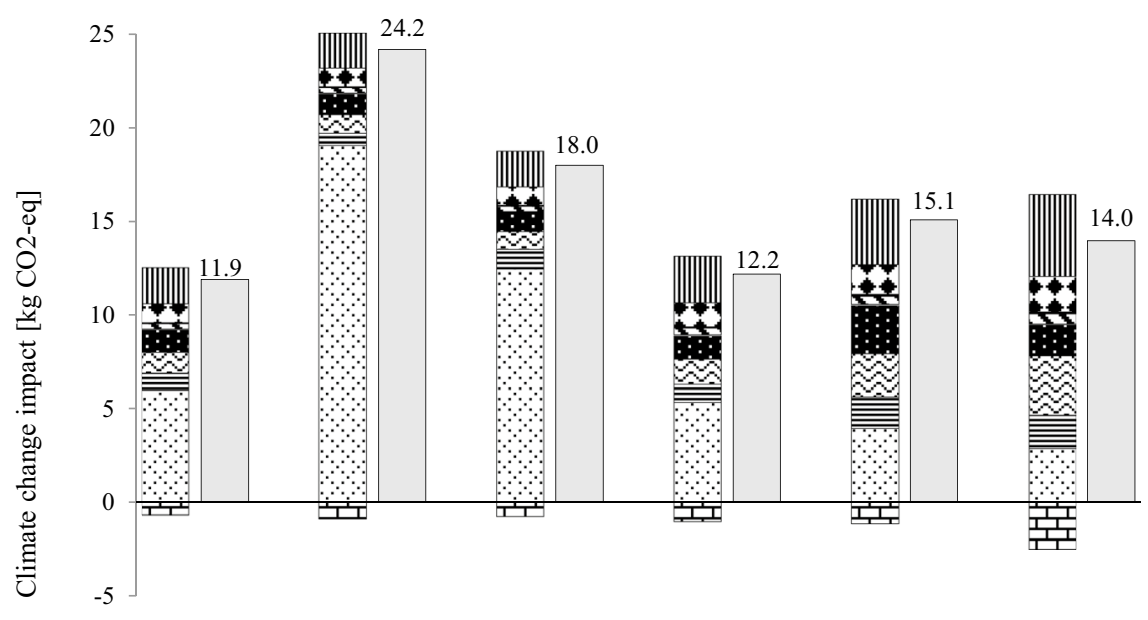

(B)

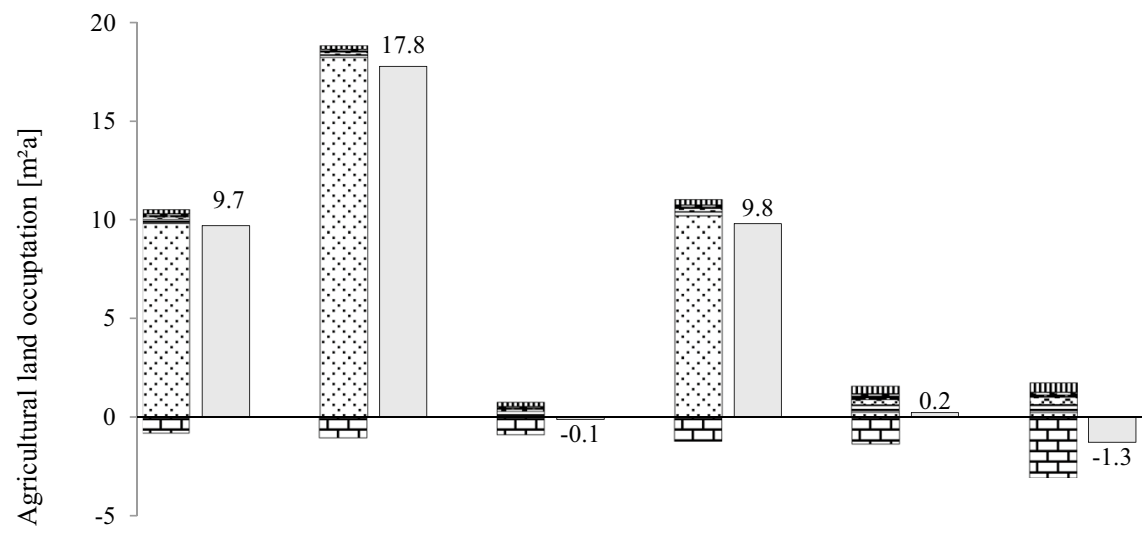

(C)

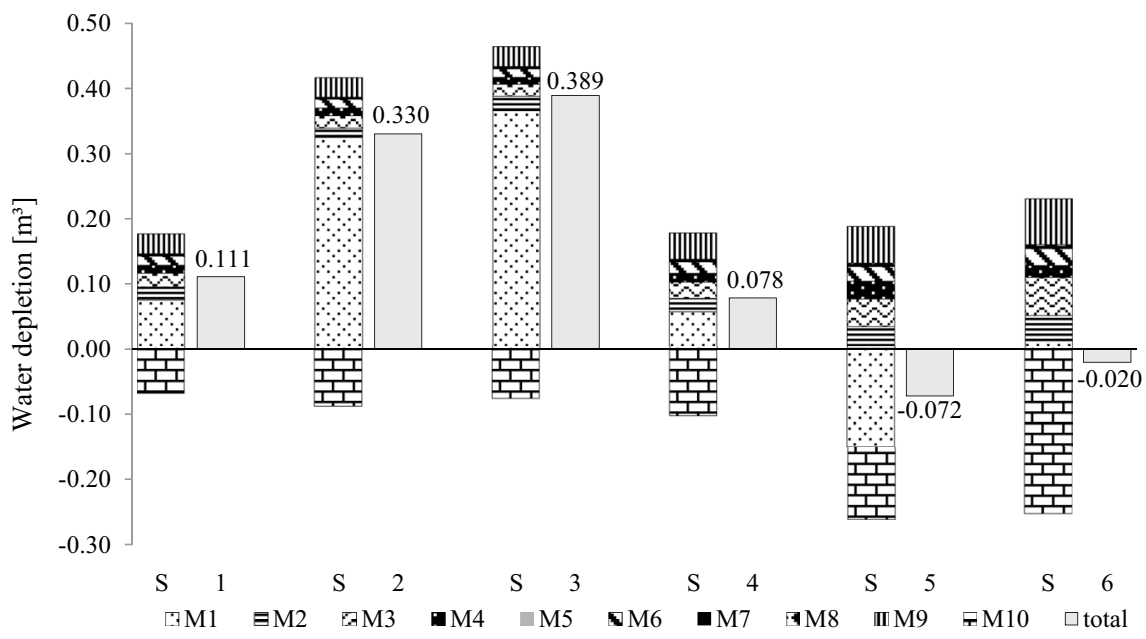

burden-free. However, the efforts in transporting the feed ingredients to the facility and in preparing and distributing the feeding substrate do increase per insect output when the conversion efficiency decreases.

Secondly, lower quality feed ingredients also lead to longer larval development times, causing higher energy consumption in the rearing stage. And lastly, the final larval biomass composition is generally less favorable when lower quality feeds are used (higher water and lower protein content). This means that more fresh insect biomass is needed to yield the desired protein output, which causes to higher impacts from processing and also compounds the above effects (higher resource use in substrate preparation and insect rearing) even further.

There is one additional effect of low system efficiency which can counterbalance the increased environmental impacts to a small extent. The waste-type scenarios have a higher rate of residual biomass output which leads to a 
larger system credit, lowering the total impact somewhat. This is especially evident in the scenario based on poultry manure (S6).

Conversely, scenarios based on feeds with larger upstream impacts can compensate these with lower resource use and impacts occurring during the rearing and processing stages. But there is a limit to this: the chicken feed scenario (S2) has such high impacts from the feed ingredients that even the highly efficient system cannot compensate this.

The efficiency of the different feed-based scenarios seems to also be reflected in the costs. Scenarios S1, S3, and $\mathrm{S} 4$ have the lowest overall costs and the highest overall feed conversion efficiencies (see scaling factors for M1) (S2 also has similarly high conversion efficiency but again is an outlier because of the feeding substrate that cannot be compensated with efficiency during rearing), whereas the waste stream scenarios are among the highest cost alternatives despite the feed ingredients entering the production system at no cost to the producer. To a lesser extent, this effect is also noticeable in the climate change impact results. This is likely due to the varying levels of energy consumption, which is an important contributor to both costs and climate change impact.

The findings of the individual economic and environmental assessments are well summarized in the combined eco-efficiency analysis of the six scenarios. Most of the feedbased scenarios are in the end similarly eco-efficient because there are trade-offs between the upstream impact and cost of a feed ingredient and its nutritional quality and influence on system performance. Higher upstream impacts and costs of the feed ingredients can be compensated by lower impacts and costs during the rearing and processing stages - and vice versa. An exception to this is the outlier scenario S2, which is characterized by very high upstream impacts and costs of the feed ingredient which cannot be compensated through high efficiency of the system.

To conclude the main findings, some results of the distiller's grains scenario S3 merit discussion. Remarkably, this scenario has similarly low ALO results as the waste stream scenarios S5-S6 but ranks among the highest impacting scenarios in the other impact indicators. This seems to be explained by the modeling method applied in the background database of Agri-footprint. Distiller's grains are a byproduct of ethanol production from maize, and the upstream impact from agricultural production is completely allocated to the ethanol due to its much higher economic value. The dried distiller's grains include only the allocated impacts from processing and therefore only have negligible impacts from ALO (van Zeist et al. 2012). Contrarily, the water depletion and climate change impact of the distiller's grains are quite high, which is explained by the water and energy intensity of the bio-ethanol production process.

\section{Sensitivity analysis}

To assess sensitivity, the eco-efficiency results of the production scenarios were calculated with two alternative functional units: $1 \mathrm{~kg} \mathrm{dm}$ dried larvae (FU2) and $1 \mathrm{~kg} \mathrm{fm}$ unprocessed larvae (FU3). The baseline functional unit is $1 \mathrm{~kg}$ crude protein from dried larvae (FU1). In comparison to the baseline FU, the eco-efficiency portfolios based on FU2 and FU3 show more distinct differences between the production scenarios and an increased range of results. Across all FU, the larvae fed on chicken feed (scenario S2) have the lowest eco-efficiency, but the distribution of the other scenario results changes with the functional unit. When using the baseline FU, all scenarios except scenario $\mathrm{S} 2$ are clustered in close proximity, exhibiting similar ecoefficiencies. When using FU2, the scenarios S4 (wheat middlings), S5 (fruit and vegetable waste), and S6 (poultry manure) are separated from the remaining scenarios and show a higher eco-efficiency. This functional unit factors out the substrate-specific protein content of the larvae and only describes the dry matter insect biomass yield. FU3 additionally disregards the differing water contents of the larvae fed on different substrates and excludes the impacts from processing. When using this $\mathrm{FU}$, the larvae fed on poultry manure can clearly be identified as the most eco-efficient option. More detailed results can be found in Appendix 5. This demonstrates that the functional unit needs to be carefully defined as this methodological choice can influence the conclusions about the eco-efficiency of insects fed on different substrates. A mass-based comparison (FU2 and FU3) may overestimate the advantageousness of waste streams as insect feed. When the larval protein yield is used instead (FU1), the differences between the feed types are mitigated, and the alternatives show similar eco-efficiencies.

Sensitivity of the results to the environmental single score impact was also assessed. The eco-efficiency portfolio of the production scenarios changes when IMPACT is used instead of ReCiPe for the single score environmental impact assessment. When using IMPACT, the range of results is smaller compared to the baseline ReCiPe, and there are two distinct clusters of scenarios: S4-S6 exhibit higher eco-efficiencies, while S1-S3 are of lower eco-efficiency (see Appendix 5). These differences primarily originate in module M1 (production of feeding substrate). To investigate this, the contributions of the separate impact categories to the single scores were analyzed for the M1 variant results. Differences in the contribution patterns between the two methods were identified with ReCiPe showing higher contributions from land use and IMPACT showing higher contributions from terrestrial ecotoxicity. Similar findings about these two impact assessment methods have been reported in the literature (Owsianiak 
et al. 2014). These discrepancies between the impact assessment methods demonstrate that decisions should not be made solely based on single score results. The weighting schemes behind the aggregated LCA results represent value judgments and environmental priorities that may not be congruent with the decision-maker's. Such scores can be useful for screening the total environmental impact, but separate midpoint or endpoint indicator results should be consulted in parallel.

\section{Benchmarking}

Overall, the results from this study are in the same range as the findings reported in literature (Table 6). It must be stressed, however, that the results from these studies are only comparable to a limited extent because of the differences in the studied systems and the applied assessment methods (inventory modeling, impact assessment method, etc.). Nevertheless, the benchmarking is useful to generally verify the results from this study. A more detailed analysis of this benchmarking can be found in Appendix 6. The literature results found in Table 6 were converted to the common functional unit of $1 \mathrm{~kg}$ protein where possible; else results were reported on a dry matter insect output basis (details on the conversion of the literature results can be found in Appendix 6).

\section{Limitations}

Several limitations of the results must be discussed. These concern data quality and representativeness, the choice of impact indicators, and the applicability of results.
The design and implementation of this study were to a great extent dependent on data availability. The definition of feeding substrates to be studied (M1 variants) and the determination of substrate-specific scaling factors relied heavily on results from literature and lab-scale feeding trials. These trials varied widely in their methods, making the results difficult to adapt to this study (e.g., converting data on feed conversion efficiency to a common metric). The need for standardization has been recognized in the literature, and a framework for insect rearing trials has recently been published (Bosch et al. 2020), which could set a basis for further LCA and eco-efficiency studies.

Moreover, the feeding substrates included in this assessment may not be representative for industrial rearing facilities, and the results therefore are only an approximation of the actual impacts. Insect rearing facilities generally use specialized feeds that are optimized for conversion efficiency. The composition of these feeds is proprietary information, and consequently no data has been published, and no such feed could be included in the assessment. However, this study did not aim for the close reliability of results for a specific rearing facility but for the generalized conclusions on the applicability of a modular eco-efficiency methodology.

There are also some inconsistencies in the data used for the cost assessment. The variable costs throughout the assessment represent the situation in Europe, adhering to the regional scope of the study. The capital costs in modules M8 and M9, however, were sourced from a Chinese trade platform because no Europe-specific comparable data was freely available. This difference in regional price levels may skew the ratio of variable to capital costs in these modules and lead to certain errors. For a more in-depth cost assessment,

Table 6 Comparison of environmental and cost assessment results for the production of dried Hermetia illucens larvae for food and feed

\begin{tabular}{|c|c|c|c|c|}
\hline Study & Functional unit & Climate change, $\mathrm{kg} \mathrm{CO}_{2}$-eq & Land use, $\mathrm{m}^{2}$ & Water depletion, $\mathrm{m}^{3}$ \\
\hline Bava et al. (2019) & $1 \mathrm{~kg}$ protein & $4-11$ & - & $2.2-2.4$ \\
\hline Bosch et al. (2019) & $1 \mathrm{~kg}$ protein & $3-19$ & $0-67$ & - \\
\hline Maiolo et al. (2020) & $1 \mathrm{~kg}$ protein & $2-5$ & - & 2.6 \\
\hline Smetana et al. (2016) & $1 \mathrm{~kg}$ protein & $2-25$ & $0-12$ & - \\
\hline Smetana et al. (2019) & $1 \mathrm{~kg}$ protein & 10 & 3 & 0.005 \\
\hline Current study & $1 \mathrm{~kg}$ protein & $12-24$ & -1 to 18 & -0.007 to 0.39 \\
\hline Ites et al. (2020) & $1 \mathrm{~kg}$ DM larvae & -6.4 to 2 & -16.8 to -0.006 & - \\
\hline Roffeis et al. $(2018,2020)$ & $1 \mathrm{~kg}$ DM larvae & 6 & 8 & 11.7 \\
\hline \multirow[t]{2}{*}{ Current study } & \multirow[t]{2}{*}{$1 \mathrm{~kg}$ DM larvae } & $5-11$ & $0-8$ & -0.003 to 0.19 \\
\hline & & Single score & & Cost \\
\hline Smetana et al. (2016) & $1 \mathrm{~kg}$ protein & -300 to $1500 \mathrm{mPt}(\mathrm{ReCiPe})$ & & - \\
\hline Smetana et al. (2019) & $1 \mathrm{~kg}$ protein & $3300 \mu \mathrm{Pt}(\mathrm{IMPACT} 2002+)$ & & - \\
\hline \multirow[t]{2}{*}{ Current study } & \multirow[t]{2}{*}{$1 \mathrm{~kg}$ protein } & $1300-3300 \mathrm{mPt}(\mathrm{ReCiPe})$ & & - \\
\hline & & $3900-10,000 \mu \mathrm{Pt}(\mathrm{IMPACT} 2002+)$ & & - \\
\hline Roffeis et al. $(2018,2020)$ & $1 \mathrm{~kg}$ DM larvae & 700 mPt (ReCiPe) & & $2.8 €$ \\
\hline Current study & $1 \mathrm{~kg}$ DM larvae & 500-1500 mPt (ReCiPe) & & $2.1-3.1 €$ \\
\hline
\end{tabular}


equipment prices specific to the European market should be determined for the processing modules.

While the focus of the impact assessment was to obtain single score results that could be used in the subsequent ecoefficiency analysis, several midpoint indicator results were also included to provide additional insights for the analysis of the production scenarios. Some areas of improvement concerning the choice of indicators were identified. First, different water depletion impact category indicator should have been chosen to comprehensively assess the water footprint of the production alternatives. The selected water depletion indicator in ReCiPe 2008 is rudimentary in comparison to other methods. The water depletion impact is also not included in the ReCiPe single score result, which was assumed at the time the impact assessment was carried out. And second, an energy consumption indicator should have been included in the assessment. It was initially assumed that the climate change indicator could sufficiently represent the impacts from energy consumption. But especially in module M1, other sources of greenhouse gas emissions are present. A comparative analysis of the energy intensities of the different production scenarios is not possible with the current selection of indicators.

And lastly, regarding the applicability of results, the ecoefficiency assessment carried out in this study is inherently of a relative nature and only useful for comparing alternative production scenarios that were economically and environmentally assessed under a common identical methodology. The benchmarking has shown that the environmental assessment is comprehensive enough to stand comparison to the results of other LCA studies of insect production. However, the results of the cost assessment should only be evaluated in conjunction with the LCA results and not be used for comparisons with processes outside the realm of the studied production system. Important cost contributors, such as labor, infrastructure, or administration, were not included in this assessment. To gain a thorough understanding of the economics of insect production, a detailed life cycle costing study must be carried out.

\section{Evaluation of the modular assessment approach}

The developed modular assessment approach proved to be efficient in assessing and modeling a large number of possible alternative production scenarios and can be further adapted to incorporate additional variations of the production system. Some new variants could be added without much effort, for example, additional processing technologies in the modules M8 (pre-processing) and M9 (drying). The only requirement is that they are modeled according to the functional unit of the respective module. The addition of new modules would require larger effort because it also necessitates the creation of new scaling factors. Adding further downstream processing modules, like lipid separation, would have consequences on the entire assessment system. Such a fractionation process is multifunctional and would require a suitable allocation method.

The extension of the system to incorporate additional insect species would entail considerably more work. Some modules may be reusable (like the feed distribution (M3), harvesting (M7), and the processing modules M8 and M9), while others need to be adapted to the insect species. For example, different insect species require different feeding substrates to thrive- the feed ingredients and the substrate's moisture content and particle size need to be modeled according to the species' requirements. Depending on the insect species, these feed requirements can also change between adult and larval stage, necessitating further differentiation in modeling. The largest effort of incorporating new species lies in the definition of new scaling factors which requires considerable amounts of data from scientific rearing trials that may not be available for many insect species.

The modular assessment approach also has certain drawbacks. The determination of modules, variants, and scaling factors requires a large up-front time investment before scenario analysis can take place. Also, certain module variant combinations can lead to redundancies or inefficiencies in the studied scenarios, which may lead to an overestimation of the impacts. For example, the scenarios that were assessed in this study contain blanching as a pre-processing step (module M8). The previous module (M7, harvesting) contains a washing step, which may be redundant because the larvae are washed during blanching anyway. Considering the low relative impact of these specific processes, the overestimate in energy and water consumption is likely insignificant in this case. But generally, this could be solved by introducing restrictions for the combination of processing modules. Alternatively, the processing modules could be aggregated into one module with module variants representing common processing routes, i.e., practical combinations of pre-processing and drying steps. For example, combining the harvesting module (M7) with M8 (pre-processing) would simplify the assessment system.

Finally, due to a lack of data, the aspect product quality could not be fully integrated into the assessment. The product quality is characterized by the nutritional composition (macronutrients, amino acids, fatty acids, etc.) and by other quality parameters (color, lipid oxidation, protein solubility, etc.) of the insect output. Higher quality products will yield higher revenues for the producer, and this is an important factor that should be included in a decision-support system. A higher potential revenue may justify more expensive or more environmentally impactful processing technologies or feeding substrates. 
There are several options for incorporating product quality into the modular assessment tool. A product quality indicator could be included as a third dimension alongside the environmental impact and cost. Alternatively, a more complex metric describing product quality variations could be used as a more holistic functional unit. Lastly, the inclusion of expected revenue into the eco-efficiency assessment could be another option. Such an approach could rely on value added instead of just production cost as the product value indicator. Detailed information on sale prices would be required for such approach. However, insect producers likely have this information and could modify the assessment tool accordingly.

\section{Conclusions and recommendations}

The inclusion of edible insects into the food system has been proposed as a solution to ensure food security without putting additional stress on the environment. This study sought to explore the most eco-efficient way to produce edible insects to aid decision-makers in sustainably upscaling the sector.

The findings from this study indicate that most of the assessed $H$. illucens production systems are similarly ecoefficient despite being based on different feeds of varying nutritional qualities, prices, and upstream environmental impacts. There are trade-offs between the impact of the feed and the impact of the rearing and processing system. Therefore, from a joined economic and environmental perspective, the choice of feeding substrate might not be crucial. Only highly processed compound feeds, such as chicken feed, should be avoided. Consequently, (prospective) insect producers should focus on which materials they can source locally, in decent quantities, and relatively constant qualities to reduce impacts from transportation and reformulation of feeds. Attention should also be given to energy and water efficiency measures, especially when feeding substrates with lower conversion efficiencies are used. The most ecoefficient processing pathway was identified as blanching followed by microwave drying. However, the insect producer's choice of processing technology will likely depend to a large extent on the desired product output. Higher quality products may justify more expensive technologies, and the most ecoefficient processing option will have to be determined on a case-by-case basis.

Existing environmental assessments of insect production varied widely in scope and methodological choices. The necessity for a common framework has already been identified in the literature (Smetana et al. 2021). The systematic approach presented in this study may offer some insight for the formulation of such a framework. Further research about the economics of insect production is needed. Ideally, the aspect product quality (i.e., nutritional properties of the output) should also be included in future assessments.

It is envisioned that within the next few years, insect products can supply a considerable amount of the European protein demand for food and feed. A method of determining eco-efficiency based on cost-analysis and modular life cycle assessment tested in the study demonstrated to be a viable approach after further adaptations to eliminate the potential double counting and redundant module combinations. Insights from this study may support prospective insect producers, legislators, and other relevant actors in their efforts to ensure a sustainable upscaling of the sector.

Supplementary information The online version contains supplementary material available at https://doi.org/10.1007/s11367-021-01986-y.

Funding Open Access funding enabled and organized by Projekt DEAL. This study has received funding from the European Union's Horizon 2020 research and innovation program under grant agreement no 861976 project SUSINCHAIN.

Data availability The datasets generated during and/or analyzed during the current study are available from the corresponding author on reasonable request.

Open Access This article is licensed under a Creative Commons Attribution 4.0 International License, which permits use, sharing, adaptation, distribution and reproduction in any medium or format, as long as you give appropriate credit to the original author(s) and the source, provide a link to the Creative Commons licence, and indicate if changes were made. The images or other third party material in this article are included in the article's Creative Commons licence, unless indicated otherwise in a credit line to the material. If material is not included in the article's Creative Commons licence and your intended use is not permitted by statutory regulation or exceeds the permitted use, you will need to obtain permission directly from the copyright holder. To view a copy of this licence, visit http://creativecommons.org/licenses/by/4.0/.

\section{References}

Alexander P, Brown C, Arneth A et al (2017) Could consumption of insects, cultured meat or imitation meat reduce global agricultural land use? Glob Food Sec 15:22-32. https://doi.org/10.1016/j.gfs. 2017.04.001

Alles MC, Smetana S, Parniakov O et al (2020) Bio-refinery of insects with pulsed electric field pre-treatment. Innov Food Sci Emerg Technol 64:102403. https://doi.org/10.1016/j.ifset.2020.102403

Bava L, Jucker C, Gislon G et al (2019) Rearing of Hermetia illucens on different organic by-products: influence on growth, waste reduction, and environmental impact. Animals 9:289. https://doi. org/10.3390/ani9060289

Bosch G, Oonincx DGAB, Jordan HR et al (2020) Standardisation of quantitative resource conversion studies with black soldier fly larvae. J Insects as Food Feed 6:95-109. https://doi.org/10.3920/ JIFF2019.0004

Bosch G, van Zanten HHE, Zamprogna A et al (2019) Conversion of organic resources by black soldier fly larvae: legislation, efficiency and environmental impact. J Clean Prod 222:355-363. https://doi. org/10.1016/j.jclepro.2019.02.270 
Boulay A-M, Bare J, Benini L et al (2018) The WULCA consensus characterization model for water scarcity footprints: assessing impacts of water consumption based on available water remaining (AWARE). Int J Life Cycle Assess 23:368-378. https://doi. org/10.1007/s11367-017-1333-8

Buxmann K, Kistler P, Rebitzer G (2009) Independent information modules-a powerful approach for life cycle management. Int J Life Cycle Assess 14:92-100. https://doi.org/10.1007/ s11367-009-0075-7

Cortes Ortiz JA, Ruiz AT, Morales-Ramos JA et al (2016) Insect mass production technologies. In: Insects as Sustainable Food Ingredients. Elsevier, pp 153-201

De Marco M, Martínez S, Hernandez F et al (2015) Nutritional value of two insect larval meals (Tenebrio molitor and Hermetia illucens) for broiler chickens: apparent nutrient digestibility, apparent ileal amino acid digestibility and apparent metabolizable energy. Anim Feed Sci Technol 209:211-218. https://doi.org/ 10.1016/j.anifeedsci.2015.08.006

Dossey AT, Morales-Ramos JA, Rojas MG (2016) Insects as sustainable food ingredients: production, processing and food applications. Academic Press

Durlinger B, Koukouna E, Broekema R et al (2017) Agri-footprint 4.0Part 1: methodology and basic principles. Agri-Footprint: Gouda, The Netherlands

EFSA Panel on Nutrition NF and FA (NDA) D Turck J Castenmiller et al (2021) Safety of dried yellow mealworm (Tenebrio molitor larva) as a novel food pursuant to Regulation (EU) 2015/2283 EFSA J 19 https://doi.org/10.2903/j.efsa.2021.6343

Goedkoop M, Heijungs R, Huijbregts M et al (2009) ReCiPe 2008. A life cycle impact assessment method which comprises harmonised category indicators at the midpoint and the endpoint level

Green A, Nemecek T, Chaudhary A, Mathys A (2020) Assessing nutritional, health, and environmental sustainability dimensions of agri-food production. Glob Food Sec 26:100406. https://doi. org/10.1016/j.gfs.2020.100406

Green A, Nemecek T, Smetana S, Mathys A (2021) Reconciling regionally-explicit nutritional needs with environmental protection by means of nutritional life cycle assessment. J Clean Prod 312:127696. https://doi.org/10.1016/j.jclepro.2021.127696

Guiné RPF, Correia P, Coelho C, Costa CA (2021) The role of edible insects to mitigate challenges for sustainability. Open Agric 6:2436. https://doi.org/10.1515/opag-2020-0206

Hellweg S, Milà i Canals L (2014) Emerging approaches, challenges and opportunities in life cycle assessment. Science 344:11091113. https://doi.org/10.1126/science. 1248361

Henry M, Gasco L, Piccolo G, Fountoulaki E (2015) Review on the use of insects in the diet of farmed fish: past and future. Anim Feed Sci Technol 203:1-22. https://doi.org/10.1016/j.anifeedsci. 2015.03.001

Hunkeler D, Lichtenvort K, Rebitzer G (2008) Environmental life cycle costing. CRC Press

ISO 14045 (2012) Environmental management - eco-efficiency assessment of product systems - principles, requirements and guidelines

Ites S, Smetana S, Toepfl S, Heinz V (2020) Modularity of insect production and processing as a path to efficient and sustainable food waste treatment. J Clean Prod 248:119248. https://doi.org/10. 1016/j.jclepro.2019.119248

Jungbluth N, Tietje O, Scholz RW (2000) Food purchases: impacts from the consumers' point of view investigated with a modular LCA. Int J Life Cycle Assess 5:134. https://doi.org/10.1007/ BF02978609

Kawasaki K, Kawasaki T, Hirayasu H et al (2020) Evaluation of fertilizer value of residues obtained after processing household organic waste with black soldier fly larvae (Hermetia illucens). Sustainability 12:4920. https://doi.org/10.3390/su12124920
Kok R (2021) Preliminary project design for insect production: part 1 - overall mass and energy/heat balances J Insects as Food Feed 1-12 https://doi.org/10.3920/JIFF2020.0055

Maiolo S, Parisi G, Biondi N et al (2020) Fishmeal partial substitution within aquafeed formulations: life cycle assessment of four alternative protein sources. Int J Life Cycle Assess 25:1455-1471. https://doi.org/10.1007/s11367-020-01759-z

Melgar-Lalanne G, Hernández-Álvarez AJ, Salinas-Castro A (2019) Edible insects processing: traditional and innovative technologies. Compr Rev Food Sci Food Saf 18:1166-1191. https://doi.org/10. 1111/1541-4337.12463

Mertenat A, Diener S, Zurbrügg C (2019) Black soldier fly biowaste treatment - assessment of global warming potential. Waste Manag 84:173-181. https://doi.org/10.1016/j.wasman.2018.11.040

Oonincx DGAB, de Boer IJM (2012) Environmental impact of the production of mealworms as a protein source for humans - a life cycle assessment. PLoS ONE 7:e51145. https://doi.org/10.1371/ journal.pone.0051145

Oonincx DGAB, van Broekhoven S, van Huis A, van Loon JJA (2015) Feed conversion, survival and development, and composition of four insect species on diets composed of food by-products. PLoS ONE 10:e0144601. https://doi.org/10.1371/journal.pone.0144601

Owsianiak M, Laurent A, Bjørn A, Hauschild MZ (2014) IMPACT $2002+$, ReCiPe 2008 and ILCD's recommended practice for characterization modelling in life cycle impact assessment: a case study-based comparison. Int J Life Cycle Assess 19:10071021. https://doi.org/10.1007/s11367-014-0708-3

Pleissner D, Smetana S (2020) Estimation of the economy of heterotrophic microalgae- and insect-based food waste utilization processes. Waste Manag 102:198-203. https://doi.org/10.1016/j. wasman.2019.10.031

Rebitzer G (2005) Enhancing the application efficiency of life cycle assessment for industrial uses. EPFL PP - Lausanne

Rödger J-M, Kjær LL, Pagoropoulos A (2018) Life cycle costing: an introduction. Life Cycle Assessment. Springer International Publishing, Cham, pp 373-399

Roffeis M, Almeida J, Wakefield M et al (2017) Life cycle inventory analysis of prospective insect based feed production in West Africa. Sustainability 9:1697. https://doi.org/10.3390/su9101697

Roffeis M, Fitches EC, Wakefield ME et al (2020) Ex-ante life cycle impact assessment of insect based feed production in West Africa. Agric Syst 178:102710. https://doi.org/10.1016/j.agsy. 2019.102710

Roffeis M, Muys B, Almeida J et al (2015) Pig manure treatment with housefly (Musca domestica) rearing - an environmental life cycle assessment. J Insects as Food Feed 1:195-214. https:// doi.org/10.3920/JIFF2014.0021

Roffeis M, Wakefield ME, Almeida J et al (2018) Life cycle cost assessment of insect based feed production in West Africa. J Clean Prod 199:792-806. https://doi.org/10.1016/j.jclepro. 2018.07.179

Saling P (2016) Eco-efficiency Assessment. pp 115-178

Saling P, Kicherer A, Dittrich-Krämer B et al (2002) Eco-efficiency analysis by basf: the method. Int J Life Cycle Assess 7:203-218. https://doi.org/10.1007/BF02978875

Salomone R, Saija G, Mondello G et al (2017) Environmental impact of food waste bioconversion by insects: application of life cycle assessment to process using Hermetia illucens. J Clean Prod 140:890-905. https://doi.org/10.1016/j.jclepro.2016.06.154

Sánchez-Muros M-J, Barroso FG, Manzano-Agugliaro F (2014) Insect meal as renewable source of food for animal feeding: a review. $\mathbf{J}$ Clean Prod 65:16-27. https://doi.org/10.1016/j.jclepro.2013.11. 068

Shorstkii I, Alles MC, Parniakov O et al (2020) Optimization of pulsed electric field assisted drying process of Black soldier fly (Hermetia illucens) larvae. Dry Technol 
Smetana S, Mathys A, Knoch A, Heinz V (2015) Meat alternatives: life cycle assessment of most known meat substitutes. Int J Life Cycle Assess 20:1254-1267. https://doi.org/10.1007/ s11367-015-0931-6

Smetana S, Mhemdi H, Mezdour S, Heinz V (2020) Pulsed electric field-treated insects and algae as future food ingredients. In: Pulsed Electric Fields to Obtain Healthier and Sustainable Food for Tomorrow. Elsevier, pp 247-266

Smetana S, Palanisamy M, Mathys A, Heinz V (2016) Sustainability of insect use for feed and food: life cycle assessment perspective. J Clean Prod 137:741-751. https://doi.org/10.1016/j.jclepro.2016. 07.148

Smetana S, Schmitt E, Mathys A (2019) Sustainable use of Hermetia illucens insect biomass for feed and food: attributional and consequential life cycle assessment. Resour Conserv Recycl 144:285296. https://doi.org/10.1016/j.resconrec.2019.01.042

Smetana S, Spykman R, Heinz V (2021) Environmental aspects of insect mass production J Insects as Food Feed 1-20. https://doi. org/10.3920/JIFF2020.0116

Steubing B, Mutel C, Suter F, Hellweg S (2016) Streamlining scenario analysis and optimization of key choices in value chains using a modular LCA approach. Int J Life Cycle Assess 21:510-522. https://doi.org/10.1007/s11367-015-1015-3

van Huis A (2013) Potential of insects as food and feed in assuring food security. Annu Rev Entomol 58:563-583. https://doi.org/10.1146/ annurev-ento-120811-153704

van Zanten HHE, Mollenhorst H, Oonincx DGAB et al (2015) From environmental nuisance to environmental opportunity: housefly larvae convert waste to livestock feed. J Clean Prod 102:362-369. https://doi.org/10.1016/j.jclepro.2015.04.106

van Zeist WJ, Marinussen M, Broekma R et al (2012) LCI data for the calculation tool Feedprint for greenhouse gas emissions of feed production and utilization. Bio-Ethanol Industry. Gouda, NL

Wernet G, Bauer C, Steubing B et al (2016) The ecoinvent database version 3 (part I): overview and methodology. Int J Life Cycle Assess 21:1218-1230. https://doi.org/10.1007/s11367-016-1087-8

Publisher's Note Springer Nature remains neutral with regard to jurisdictional claims in published maps and institutional affiliations.

\section{Authors and Affiliations}

\section{Raphaela Spykman $^{1}$ - Sayed Mahdi Hossaini ${ }^{1}$ - Daniela A. Peguero ${ }^{2}$ - Ashley Green ${ }^{2,3}$ - Volker Heinz ${ }^{1}$. Sergiy Smetana ${ }^{1}$}

1 German Institute of Food Technologies (DIL E.V.), Quakenbrück, Germany

2 Laboratory of Sustainable Food Processing, ETH Zurich, Zurich, Switzerland
Life Cycle Assessment Research Group, Agroscope, Zurich, Switzerland 